\title{
REVIEW
}

\section{New insights into the ecology of the globally significant uncultured nitrogen-fixing symbiont UCYN-A}

\author{
Hanna Farnelid ${ }^{1,2, *}, K^{2}$ dra Turk-Kubo ${ }^{1}$, María del Carmen Muñoz-Marín ${ }^{1,3}$, \\ Jonathan P. Zehr ${ }^{1}$ \\ ${ }^{1}$ Ocean Sciences Department, University of California, Santa Cruz, CA 95064, USA \\ ${ }^{2}$ Centre for Ecology and Evolution in Microbial Model Systems (EEMiS), Linnaeus University, 39234 Kalmar, Sweden \\ ${ }^{3}$ Departamento de Bioquímica y Biología Molecular, Edificio Severo Ochoa, planta 1, Universidad de Córdoba, \\ 14071-Córdoba, Spain
}

\begin{abstract}
Cyanobacterial nitrogen-fixers (diazotrophs) play a key role in biogeochemical cycling of carbon and nitrogen in the ocean. In recent years, the unusual symbiotic diazotrophic cyanobacterium Atelocyanobacterium thalassa (UCYN-A) has been recognized as one of the major diazotrophs in the tropical and subtropical oceans. In this review, we summarize what is currently known about the geographic distribution of UCYN-A, as well as the environmental factors that govern its distribution. In addition, by compiling UCYN-A nifH sequences from the GenBank no. database as well as those from nifH gene amplicon next generation sequencing studies, we present an in-depth analysis of the distribution of defined UCYN-A sublineages (UCYN-A1, UCYN-A2 and UCYN-A3) and identify a novel sublineage, UCYN-A4, which may be significant in some environments. Each UCYN-A sublineage exhibited a remarkable global distribution pattern and several UCYN-A sublineages frequently co-occurred within the same sample, suggesting that if they represent different ecotypes they have overlapping niches. Recently, single cell visualization techniques using specific probes targeting UCYN-A1 and UCYN-A2 and their respective associated eukaryotic partner cells showed that the size of the consortia and the number of UCYN-A cells differed between these 2 sublineages. Combined, the results highlight that UCYN-A sublineages likely have different physiological requirements, which need to be accounted for in future studies. Furthermore, based on our increasing knowledge of the diversity of the UCYN-A lineage, we discuss some of the limitations of currently used cultivation-independent molecular techniques for the identification and quantification of UCYN-A.
\end{abstract}

KEY WORDS: UCYN-A - Symbiosis - nifH - qPCR - Next generation amplicon sequencing · CARD-FISH $\cdot$ Braarudosphaera bigelowii

\section{INTRODUCTION}

In the oceans, the availability of fixed nitrogen $(\mathrm{N})$ is an important factor that limits biological productivity (Ryther \& Dunstan 1971, Moore et al. 2013). Nitrogen $\left(\mathrm{N}_{2}\right)$ fixation is an enzyme-mediated process that is

*Corresponding author: hannafarnelid@gmail.com found among diverse lineages of Bacteria and Archaea, providing biologically available ammonium $\left(\mathrm{NH}_{4}{ }^{+}\right.$) from dinitrogen gas. $\mathrm{N}_{2}$-fixers (diazotrophs) can support up to $50 \%$ of the new production (Karl et al. 1997) and thereby play a central role in the fixation of carbon $\left(\mathrm{CO}_{2}\right)$ and its export out of the photic zone.

() The authors 2016. Open Access under Creative Commons by Attribution Licence. Use, distribution and reproduction are unrestricted. Authors and original publication must be credited. 
For many years, the paradigm was that $\mathrm{N}_{2}$ fixation in the oceans was due primarily to Trichodesmium (Capone et al. 1997, 2005) and diatom symbionts (e.g. Villareal \& Carpenter 1989, Villareal 1990, 1991, 1994, Subramaniam et al. 2008) and was restricted to warm, oligotrophic waters in tropical seas. However, using molecular approaches targeting the nifH gene, which encodes the iron protein of the nitrogenase enzyme, additional marine diazotrophs including unicellular cyanobacteria and heterotrophic bacteria were discovered in the 1990s (Zehr et al. 1998, 2001). Today it is recognized that unicellular cyanobacteria, including the uncultivated Atelocyanobacterium thalassa (UCYN-A) and Crocosphaera watsonii (UCYNB), contribute significantly to global $\mathrm{N}_{2}$ fixation and may equal that of Trichodesmium (Montoya et al. 2004, Moisander et al. 2010). Early studies indicated that the UCYN-A group was of particular interest, as a fragment of its nifH gene was recovered from multiple ocean basins including the North Pacific and North Atlantic (Zehr et al. 1998, 2001, Falcón et al. 2004, Church et al. 2005a, Langlois et al. 2005, Fong et al. 2008). UCYN-A nifH genes and nifH gene transcripts, a proxy for active $\mathrm{N}_{2}$ fixation, were found at higher latitudes and deeper in the water column than Trichodesmium (Moisander et al. 2010). Recent studies also indicated that the distribution of UCYN-A goes beyond that of the oligotrophic oceans, and thereby further extends the known geographic range of $\mathrm{N}_{2}$ fixation. Since the discovery of UCYN-A, knowledge of the global distribution and significance of UCYN-A has continued to expand but there remain large unknowns about its ecology and physiology.

Observations of the transcription pattern of the UCYN-A nifH gene (Church et al. 2005b, Zehr et al. 2007), with expression during the day, hinted at a different physiology compared to other unicellular $\mathrm{N}_{2}$ fixing cyanobacteria. Subsequently, sequencing of the UCYN-A genome revealed an extremely unusual phototrophic microorganism that lacked the genes for oxygenic photosynthesis, $\mathrm{CO}_{2}$ fixation and the entire tricarboxylic acid (TCA) cycle, as well as other metabolic pathways (Zehr et al. 2008, Tripp et al. 2010). The significant genome reduction found in these studies led to the hypothesis that UCYN-A must live in symbiosis. Shortly after, a small prymnesiophyte (haptophyte), related to Braarudosphaera bigelowii, was identified as the symbiotic partner cell (Thompson et al. 2012, Hagino et al. 2013). This relationship is the only known example of a symbiosis between a diazotroph and a haptophyte and resembles that of the single cell associations that may have led to the evolution of plastids (Zehr 2015). The basis of this symbiosis is the exchange of fixed carbon $\left(\mathrm{C}_{i}\right.$ from the phototrophic eukaryote) and fixed $\mathrm{N}_{2}$ (from the diazotrophic UCYN-A) (Thompson et al. 2012, Krupke et al. 2013, 2015). Further, the reduced genome of UCYN-A and tight coupling of $\mathrm{N}$ and $\mathrm{C}$ transfers between UCYN-A and its eukaryotic partner suggests a mutually beneficial and obligate relationship (Thompson et al. 2012, Krupke et al. 2014, 2015). Recent studies suggest that UCYN-A and its eukaryotic partner cell have likely co-evolved (Bombar et al. 2014, Cornejo-Castillo et al. 2016), yet the nature of the physical association between the cells is currently not well characterized (Zehr 2015).

Amplicon sequencing of the nifH gene, both using clone and next generation sequencing libraries and targeted quantitative PCR (qPCR) assays have continued to expand our knowledge of the distribution patterns of UCYN-A. Recently, genetic diversity among UCYN-A nifH sequences was reported and 3 sublineages were defined based on the sequences available in GenBank at the time (Thompson et al. 2014). Currently, there are 2 genome sequences from 2 different UCYN-A sublineages (Zehr et al. 2008, Tripp et al. 2010, Bombar et al. 2014). The organisms, UCYN-A1 and UCYN-A2, have similar gene content but also show remarkable differences (Bombar et al. 2014). The eukaryotic partner cell for UCYN-A2 was identified as being closely related, but not identical to the prymnesiophyte partner of UCYN-A1 (based on 18S rRNA gene sequence similarity; Thompson et al. 2012, 2014). Sequencing of these genomes and identification of the associated eukaryotic cells have been critical milestones in the study of UCYN-A, without which the recent advances in knowledge of this unusual symbiosis would have been impossible. For example, whole genome expression patterns of UCYN-A were recently studied as part of a large metatranscriptomic effort during the Tara-Oceans Expedition, and specific molecular probes have been developed which have enabled, for the first time, the visualization of UCYN-A1 and UCYN-A2 and their respective partner cells (Cabello et al. 2016, CornejoCastillo et al. 2016) .

In this review, we discuss current knowledge about UCYN-A with respect to recent methodological milestones. To identify global distribution patterns of UCYN-A, we synthesized data from all studies reporting UCYN-A abundances using quantitative techniques. In addition, we compiled all available UCYN-A nifH gene sequences, including GenBank $\mathrm{nr}$ database sequences as well as those reported from next generation sequencing studies. With this significant increase in numbers of sequences, a novel 
UCYN-A sublineage was identified and patterns in the global distribution of the UCYN-A sublineages begin to emerge. We also discuss recent methodological advancements in visualization techniques, which have provided valuable insights into the morphology and physiology of UCYN-A and the eukaryotic partner cell.

\section{ESTIMATION OF UCYN-A N 2 FIXATION RATES, GLOBAL DISTRIBUTION AND ABUNDANCES}

Since UCYN-A has not yet been cultured and it frequently co-occurs with other diazotrophs, studying specific $\mathrm{N}_{2}$ fixation rates by UCYN-A is difficult. By size-partitioning the bulk seawater community into larger and smaller size fractions, it has been found that the smaller size fraction can at times dominate water column $\mathrm{N}_{2}$ fixation rates (Montoya et al. 2004, Garcia et al. 2007, Biegala \& Raimbault 2008, Bonnet et al. 2009, Church et al. 2009, Benavides et al. 2011). The importance of unicellular cyanobacteria has been inferred from regions where $\mathrm{N}_{2}$ fixation was measured in small size-fractions along with the presence and, in some cases, high abundances of nifH genes from unicellular cyanobacteria (including, for example, UCYN-A and UCYN-B). The small sizefraction (generally defined as 0.2 to $10 \mu \mathrm{m}$ in most of these studies) is frequently dominated by UCYN-A, and significant $\mathrm{N}_{2}$ fixation rates have therefore been attributed to UCYN-A at, for example, Stn ALOHA in the North Pacific (Montoya et al. 2004, Church et al. 2009). Interestingly, UCYN-A has not been detected exclusively in the small size-fraction (Benavides et al. 2016, Cornejo-Castillo et al. 2016), suggesting there is a size distribution within the UCYN-A population. Consequently, size-fractionation may exclude UCYN-A if they are associated with a larger eukaryotic cell, and thereby $\mathrm{N}_{2}$ fixation rates by UCYN-A could have been underestimated.

With recent single cell methodological developments, the metabolic activity of specific UCYN-A cells can be studied. Using halogenated in situ hybridization (HISH) or catalyzed reporter depositionfluorescence in situ hybridization (CARD-FISH) in combination with stable isotope labeling experiments and high-resolution nanometer scale secondary ion mass spectrometry (nanoSIMS), it was demonstrated that a large fraction of the fixed $\mathrm{N}$ was transferred to the associated eukaryotic partner, while a smaller fraction of fixed $\mathrm{C}$ was transferred between the eukaryotic cell and UCYN-A (Thompson et al. 2012, Krupke et al. 2015). However, the $\mathrm{N}_{2}$ fixation rates measured for single UCYN-A cells (Thompson et al. 2012, Krupke et al. 2013, 2015) were lower than expected based on modeled rates determined using growth and biomass of UCYN-A (Goebel et al. 2008). The cellular ${ }^{13} \mathrm{C}$ and ${ }^{15} \mathrm{~N}$ enrichments may be underestimated due to the decrease of signal in association with CARD-FISH analysis, a necessary technique to identify UCYN-A cells prior to nanoSIMS analysis (Musat et al. 2014). Although nanoSIMS studies targeting UCYN-A are thus far limited in both numbers and geographic coverage, it will likely become an important tool for determining the range of cell-specific $\mathrm{N}_{2}$ fixation rates as well as physiological responses of UCYN-A and its eukaryotic partner cell to perturbations, which will result in more accurate estimates of the contribution to marine $\mathrm{N}_{2}$ fixation.

Since the first discovery of unicellular cyanobacterial diazotrophs, nifH gene PCR amplicon libraries and species-specific nifH gene qPCR assays have been used in numerous studies at various locations to detect the presence of, and to quantify, genes and/or transcripts. Wide distribution patterns, high abundances and transcriptional activity of UCYN-A nifH genes have been reported from diverse locations, further supporting the significance of UCYN-A to marine $\mathrm{N}_{2}$ fixation. In the tropical oligotrophic ocean, abundances of close to $10^{7}$ nifH gene copies $1^{-1}$ have been reported (Fig. 1, Table S1 in Supplement 1 at www.int-res.com/articles/suppl/a077p125_supp. pdf) which corresponds to high cellular abundances of UCYN-A. Compared to Trichodesmium, which tends to be more abundant in the upper water column (Luo et al. 2012), UCYN-A were found to occupy greater depths (down to $\sim 150 \mathrm{~m}$ ) and were present at higher latitudes, extending the previously known $\mathrm{N}_{2}$ fixation domains (Moisander et al. 2010). Interestingly, recent studies report UCYN-A presence at diverse marine locations and environmental conditions including coastal, high latitude, N-replete and hypersaline environments, as well as in marine sediments and within copepod guts (Brown \& Jenkins 2014, Bentzon-Tilia et al. 2015, Messer et al. 2015, Scavotto et al. 2015). Using CARD-FISH, Cabello et al. (2016) detected UCYN-A in surface waters spanning the circumglobal MALASPINA expedition transect, thereby broadening the knowledge of UCYN-A presence in significant numbers to previously undersampled regions such as the Indian Ocean (Fig. 1). These findings underscore the fact that the known distribution of this unusual and versatile diazotroph is continuing to expand, which calls for a continuous re-evaluation of the significance of UCYN-A to global marine $\mathrm{N}_{2}$ fixation. 


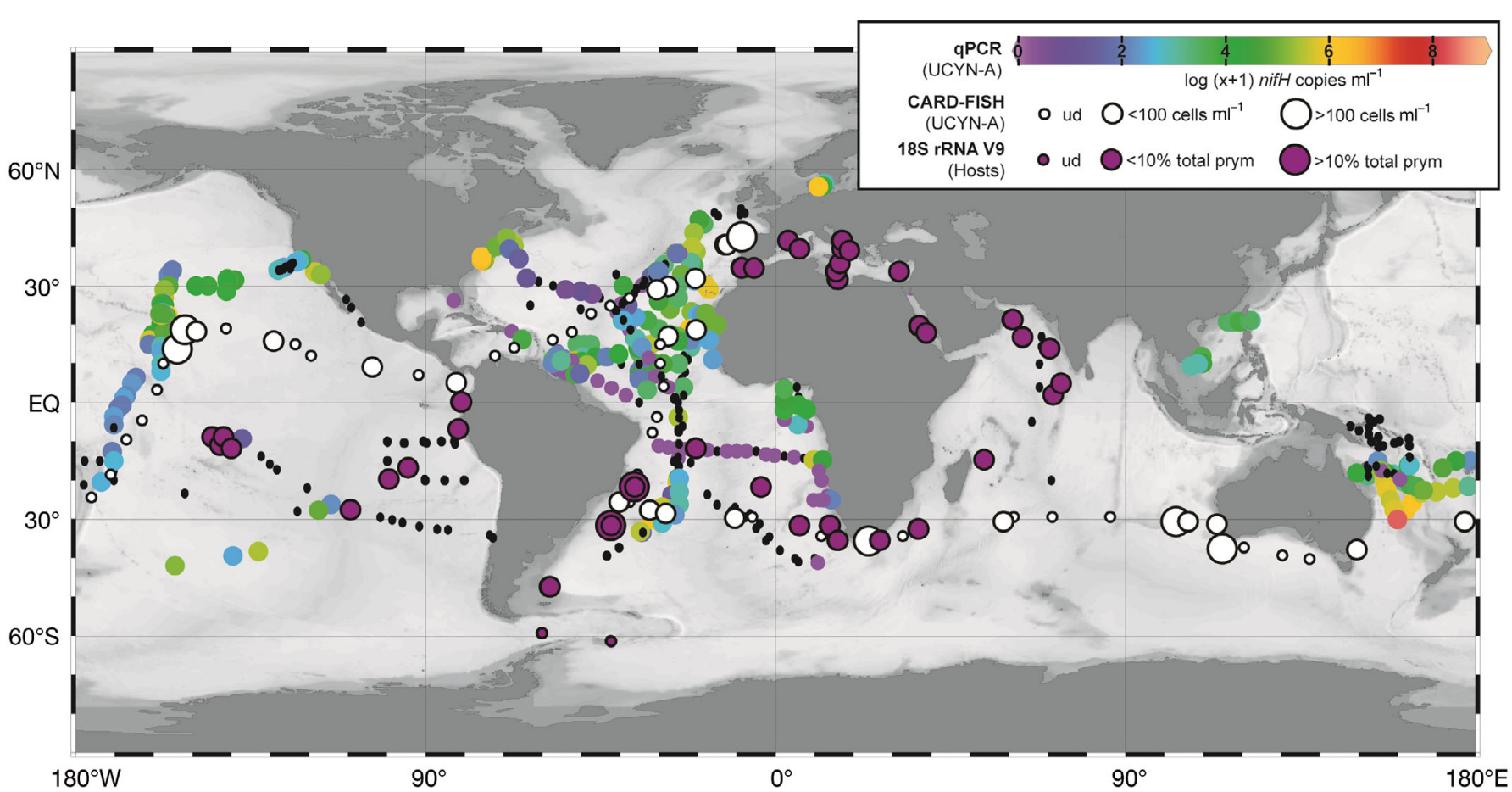

Fig. 1. Global distribution of Atelocyanobacterium thalassa (UCYN-A). Compilation of all published UCYN-A association abundance data acquired using TaqMan ${ }^{\circledR}$ qPCR, catalyzed reporter deposition-fluorescence in situ hybridization (CARDFISH), and variable region tag 18S rRNA gene-based approaches. Table S2 in Supplement 2 at www.int-res.com/articles/ suppl/a077p125_supp.xlsx summarizes the qPCR-based studies included. CARD-FISH and 18S rRNA gene V9 tag data were adapted from Cabello et al. (2016). For each station, the maximum UCYN-A abundances reported using any of the TaqMan ${ }^{\circledR}$ based assays, converted to $\log (x+1)$ nifH copies $l^{-1}$, are displayed as colored dots. Small purple dots: UCYN-A below quantification limits of the qPCR assay used in the source study; small black dots: UCYN-A was undetected. CARD-FISH and 18S rRNA gene V9 tag data from Cabello et al. (2016) are overlaid using white and purple circles, respectively

\section{RESPONSE OF UCYN-A TO ENVIRONMENTAL VARIABLES AND NUTRIENT ADDITION MANIPULATIONS}

The distribution and activity of diazotrophs is believed to be controlled by a number of parameters including temperature, nitrogen-to-phosphorus (N:P) ratios, and iron ( $\mathrm{Fe}$ ) (Goebel et al. 2010, Moisander et al. 2010, Ward et al. 2013). Currently, the nutrients limiting UCYN-A growth and the other factors that control abundances such as grazing and viral lysis are not well understood (Sohm et al. 2011). In a study in the South Pacific Ocean, UCYN-A abundances increased when either organic $\mathrm{C}$ or Fe were added to incubation experiments, and maximum net growth rates of $0.19 \mathrm{~d}^{-1}$ were reported (Moisander et al. 2012). In contrast, $P$ alone did not have an impact on UCYN-A growth (Moisander et al. 2012). In the North Atlantic Ocean, aerosol input of Fe may relieve diazotrophs from Fe limitation, and indeed UCYN-A abundances were recently shown to correlate with input of North African aerosols (Ratten et al. 2015). In a previous study in the North Atlantic Ocean, UCYN-
A nifH expression increased in $\mathrm{P}$ addition treatments (Turk-Kubo et al. 2012). However, despite increases in UCYN-A nifH expression, $\mathrm{P}$ additions did not enhance $\mathrm{N}_{2}$ fixation rates or UCYN-A abundances (Turk-Kubo et al. 2012). The presence of biologically available $\mathrm{N}$ is thought to inhibit nitrogenase activity (Dixon \& Kahn 2004). However, substantial $\mathrm{N}_{2}$ fixation in N-replete waters (Knapp 2012) and lack of inhibition of $\mathrm{N}_{2}$ fixation activity in nitrate amended cultures of the unicellular diazotrophic cyanobacterium Crocosphaera (Dekaezemacker \& Bonnet 2011) indicate that the regulation of $\mathrm{N}_{2}$ fixation activity and growth of diazotrophs may be more complex. In a bioassay experiment in the North Atlantic, UCYN-A nifH abundances increased in both ammonium nitrate and ammonium nitrate and phosphorus treatments (Langlois et al. 2012). Interestingly, near the Cape Verde islands, inhibition of UCYN-A nifH expression and $\mathrm{N}_{2}$ fixation was not observed when incubations were amended with ammonium nitrate (Krupke et al. 2015). In addition, although neither UCYN-A nifH expression nor bulk $\mathrm{N}_{2}$ fixation measurements showed a clear response to nutrient amend- 
ments, nanoSIMS showed that single-cell UCYN-A $\mathrm{N}_{2}$ and $\mathrm{CO}_{2}$ fixation differed between treatments with a positive response of $\mathrm{N}_{2}$ fixation activity to $\mathrm{Fe}$ and $\mathrm{P}$ additions (Krupke et al. 2015). Taken together, these results illustrate the complexity of nutrient limitations in diazotrophs and the difficulty of interpreting links between species-specific nifH gene expression and $\mathrm{N}_{2}$ fixation rates from a mixed community.

\section{INCREASING AMOUNTS OF UCYN-A nifH SEQUENCES REVEAL NOVEL SUBLINEAGES}

Genetic diversity has been linked to identification of niche-specific ecotypes within several highly abundant marine bacteria such as Synechococcus and Prochlorococcus, as well as the less abundant unicellular $\mathrm{N}_{2}$-fixing cyanobacterium Crocosphaera (e.g. Webb et al. 2009, Coleman \& Chisholm 2010, Bench et al. 2013, Kashtan et al. 2014, Sohm et al. 2016). UCYN-A was once thought to be an organism of broad distribution but potentially low genetic diversity (Tripp et al. 2010). However, because of the standard of analyzing amino acid sequences as an indicator of diversity for functional genes, variation on the nucleic acid level of the UCYN-A nifH gene sequences was for a long time undetected. Although almost identical at the amino acid level, UCYN-A nifH nucleic acid sequences cluster into several sublineages, and based on this observation, Thompson et al. (2014) defined 3 distinct sublineages: UCYN-A1, UCYN-A2 and UCYN-A3. The UCYN-A1 sublineage is represented by the nifH sequence of the first UCYN-A genome sequenced, sampled from Stn ALOHA in the North Pacific Subtropical Gyre (Zehr et al. 2008, Tripp et al. 2010). The UCYN-A2 sublineage is represented by the nifH sequence of a genome sequenced from a population of UCYN-A cells sampled from the Scripps Institute of Oceanography (SIO) pier at La Jolla, California, USA (Bombar et al. 2014). Thompson et al. (2014) also defined a third sublineage, UCYN-A3, but a representative of this sublineage has not yet had its genome sequenced. Genome sequencing of UCYNA1 and UCYN-A2 revealed that these 2 sublineages were highly similar in gene content, suggesting that they are adapted to a similar lifestyle (Bombar et al. 2014). However, despite the high similarity in gene content between the 2 genomes, the shared genes were on average only $86 \%$ similar on the amino acid level, indicating that species divergence has occurred from a common ancestor (Bombar et al. 2014, Cornejo-Castillo et al. 2016). Recent CARD-FISH observations suggest high fidelity and co-evolution between UCYN-A1 and UCYN-A2 and the respective eukaryotic partner for each sublineage (Cabello et al. 2016, Cornejo-Castillo et al. 2016). However, as these techniques have been used in relatively few studies, the question of host fidelity remains open. As with other marine cyanobacteria, the co-occurrence of multiple UCYN-A sublineages and/or forming an association with multiple eukaryotic partner cells may have significant impacts in the response to different environmental conditions, and consequently $\mathrm{N}_{2}$ fixation activity.

In recent years, nifH amplicon sequencing using next generation sequencing technologies have greatly increased the number of nifH sequences (e.g. Farnelid et al. 2011, Bentzon-Tilia et al. 2015, Messer et al. 2015, 2016, Turk-Kubo et al. 2015, Xiao et al. 2015, Cheung et al. 2016). Compared to traditional clone library studies, sublineages present at low abundances are more likely to be recovered using next generation sequencing, which aids our efforts to describe novel UCYN-A sublineages. To investigate this, we compiled nifH UCYN-A sequences from GenBank (available as of 17 December 2015) as well as those reported from next generation sequencing studies (Fig. 2). Briefly, raw read data from the Danish Strait (Bentzon-Tilia et al. 2015), South Australian Bight (Messer et al. 2015) and Arafura and Coral Seas (Messer et al. 2016), including the New Caledonia lagoon (Turk-Kubo et al. 2015), were obtained from the Sequence Read Archive (SRA) at the National Center for Biotechnology Information (NCBI). Raw reads were merged, when possible, using PEAR (Zhang et al. 2014), quality filtered using a phred score of 20 in QIIME (Caporaso et al. 2010), and chimeras were removed using the 'usearch61' de novo chimera check algorithm (Edgar et al. 2011). Potential UCYN-A sequences were identified via clustering with UCYN-A sequences from Thompson et al. (2014) using CD-HIT-EST or CD-HIT-EST-2D (Huang et al. 2010) at $90 \%$ nt similarity. Sequences with stop codons or gaps were removed from the analysis after import into ARB (Ludwig et al. 2004) and translation into amino acid sequences. A majority of reads from the South Australian Bight were removed due to stop codons and/or gaps. Neighbor joining trees were constructed in ARB to identify the few representative sequences that had $>90 \%$ nt similarity to UCYN-A but were more closely related to other unicellular cyanobacteria such as Cyanothece. Data from Farnelid et al. (2011) were not included due to the short sequence length resulting from early 454-pyrosequencing studies, and data from Xiao et al. (2015) were not included because $<25$ 
A

North Pacific
South Pacific
Japan \& South China Seas
Arafura \& Coral Seas
South Australian Bight
North Atlantic
Danish Strait
Mediterranean Sea

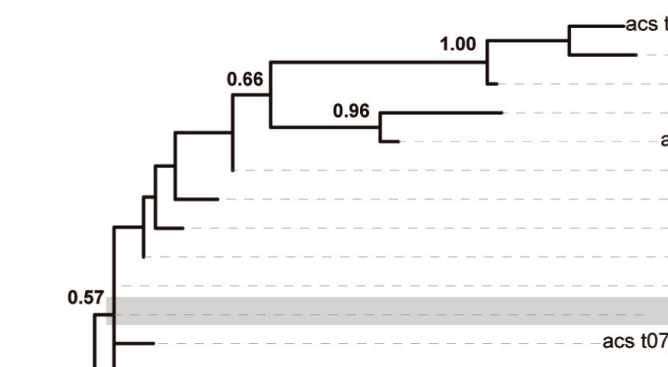

s t07_CTD11_45m_75848
- nc 60353 i 1411
-359840974 acs CTD14.1M_107261 acs CTD13.15M_112366 acs CTD19.5M_207196 gi $35 \overline{9} 840976$ acs CTD13.15M 92892 sab Z2_1b_194692 gi 445067160 gi 213578830

acs t07_CTD14_120m_203015 gi 445067072 gi 167444374 gi 445067028 acs CTD19.5M_158032 acs CTD20.30M 212420 acs CTD20.30M_60797 acs CTD14.1M_201638

acs ss2012 t07_CTD11_5m_70818 acs ss2012_t07_CTD17_5m_103927 acs CTD19.5M_119176 acs CTD10.5M 23422 acs CTD20.30M_66003 acs ss2012 t07 CTD15 90m 89010 acs ss2012 t07_CTD10_5m_97472 sab Z2_1b_50462 sab Z1 1S 191307 sab Z5_1S_15934 ds 10071 acs ss2012 t07 CTD10 56m 16272 acs ss2012_t07_CTD1_0m_169113 sab Z4_1S_116050 acs CTD22.80M 113578 ds 4102 UCYN-A2* gi 671395380 sab Z3_1b_202263 acs CTD10.5M_30994 acs ss2012 t07 CTD11 45m 90747 acs ss2012 t07_CTD13 5m 44464 acs CTD13.15M_76171 ds 9293 ds 12341 ds 10376 nc 59119887 nc 59119 acs ss2012_t07_CTD11_45m_126844 acs ss2012 t07 CTD10 56m 185864 gi 308209564 gi 308209568 acs CTD8 $5 \mathrm{M} 138680$ acs CTD20.30M_181933 acs ss2012 t07_CTD14_120m_186873 acs CTD10.5M 7505 acs CTD10.5M_66616 ds 3214 ds 5244 ds 4484 nc 591198536 Crocosphaera watsoni (UCYN-B; gi 67922883) uncult. marine bact. (UCYN-C; gi 315190853 ) cyanobacterium endosymbiont of $R$. gibba (gi 57864866)

Cyanothece sp. (gi 2209096)

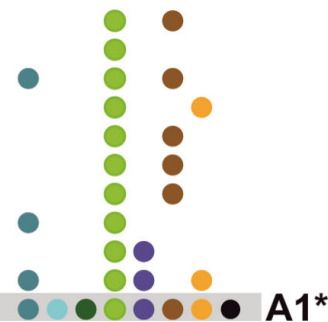

$A 1^{*}$

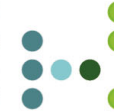

O

O

○

8

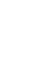

100

0

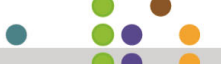

A4
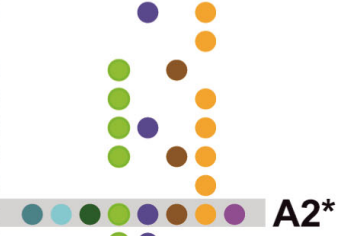

A2*

0

\begin{tabular}{|c|c|c|c|c|c|c|c|c|c|c|}
\hline \multirow[b]{2}{*}{ Rep. Seq. name } & \multicolumn{4}{|c|}{ total number of reads in ngs datasets } & \multirow[b]{2}{*}{$\begin{array}{r}\text { North } \\
\text { Pacific }\end{array}$} & \multicolumn{5}{|c|}{ total number of Genbank sequences from each region } \\
\hline & $\begin{array}{r}\text { New } \\
\text { Caledonia } \\
(n c)\end{array}$ & $\begin{array}{r}\text { Arafura \& } \\
\text { Coral Seas } \\
\text { (acs) }\end{array}$ & $\begin{array}{c}\text { South } \\
\text { Australian } \\
\text { Bight (sab) }\end{array}$ & $\begin{array}{r}\text { Danish } \\
\text { Strait (ds) }\end{array}$ & & $\begin{array}{l}\text { South } \\
\text { Pacific }\end{array}$ & $\begin{array}{r}\text { Japan \& } \\
\text { outh China } \\
\text { Seas }\end{array}$ & $\begin{array}{r}\text { North } \\
\text { Atlantic }\end{array}$ & $\begin{array}{c}\text { Danish } \\
\text { Strait }\end{array}$ & MedSea \\
\hline $\begin{array}{r}\text { gi } 671395380 \\
\text { (UCYN-A2) }\end{array}$ & 215549 & 4546 & 282 & 18429 & 86 & 5 & 7 & 53 & 25 & 13 \\
\hline $\begin{array}{r}\text { gi } 213578830 \\
\text { (UCYN-A1) }\end{array}$ & 41187 & 9146 & 288 & 118 & 273 & 13 & 12 & 18 & & \\
\hline $\begin{array}{r}\text { sab Z1_1S_191307 } \\
\text { (UCYN-A4) }\end{array}$ & 14 & 1 & 117 & 5763 & & & & & & \\
\hline $\begin{array}{l}\text { gi } 308209564 \\
\text { (UCYN-A3) }\end{array}$ & 481 & 879 & & & 2 & 6 & & 25 & & 3 \\
\hline
\end{tabular}


total UCYN-A reads were identified. When clustered at $97 \%$ nucleic acid similarity (CD-HIT-EST), and after removing clusters that comprised less than $0.1 \%$ of the total UCYN-A sequences from a given study, 59 nifH UCYN-A operational taxonomic units (OTUs) were identified (Fig. 2, Table S2 in Supplement 2 at www.int-res.com/articles/suppl/a077p125_ supp.xlsx). As expected, the next generation sequencing datasets greatly increased the number of nifH UCYN-A sequences over those present in the $\mathrm{nr}$ database of GenBank (GenBank: 819 reads; TurkKubo et al. 2015: 268943 reads; Messer et al. 2015: 781 reads; Messer et al. 2016: 18331 reads; BentzonTilia et al. 2015: 25841 reads; Table S2 in Supplement 2). The large numbers of sequences produced by next generation platforms provide an emerging pattern of UCYN-A nifH sublineages. Notably, due to the high similarity between the UCYN-A sequences, the previously identified sublineages are not well supported by bootstrap values in this analysis (Fig. 2A). To allow for comparisons in geographic distribution, relative abundances and qPCR assay specificity we therefore chose to focus on the dominating OTU within each sublineage, referred to here as the representative OTU (Fig. 2B).

In agreement with GenBank sequences, a majority of the next generation sequences affiliated with UCYN-A1 and UCYN-A2, and are reported from diverse ocean basins worldwide (Fig. 2A, Table S2). UCYN-A2 sequences frequently co-occur with UCYN-A1. However in some studies, UCYN-A2 sequences have been detected while UCYN-A1 sequences were not; e.g. the SIO Pier in the Gulf of Santa Catalina (Thompson et al. 2014), Heron Reef in the Coral Sea (Hewson et al. 2007) and the eastern Mediterranean Sea (Man-Aharonovich et al. 2007). Out of all UCYN-A nifH sequences in GenBank, the representative sequences of UCYN-A1 and UCYNA2 correspond to 58.4 and $23.1 \%$ of the sequences, respectively (Table $\mathrm{S} 2$ ). Interestingly, the relative abundance of the UCYN-A2 representative OTU dominated next generation sequencing studies from the Coral Sea (80.1\%; Turk-Kubo et al. 2015) and the Danish Strait (71.3\%; Bentzon-Tilia et al. 2015). In addition, the UCYN-A2 representative OTU was consistently present in the next generation sequencing studies (Fig. 2). This illustrates that the total number of sequences recovered from each UCYN-A sublineage is likely to be largely biased by the sampling location and sequencing depth used in the study. Sequences affiliated with the UCYN-A3 sublineage have previously been reported from near the Cape Verde Islands in the tropical North Eastern Atlantic (G. Wheeler, direct submission to GenBank) at Stn ALOHA in the North Pacific (Zehr et al. 2007), in the eastern Mediterranean Sea (Man-Aharonovich et al. 2007, Le Moal et al. 2011) and the South Pacific Gyre (Halm et al. 2012). The UCYN-A3 representative OTU corresponds to $4.4 \%$ of the total nifH UCYN-A sequences in GenBank (Fig. 2B, Table S2). Within the next generation sequencing datasets, the representative UCYN-A3 sequence type was present at relative abundances of 4.8 and $0.2 \%$ in the Arafura and Coral Seas (Messer et al. 2016) and the Noumea Lagoon in New Caledonia (Turk-Kubo et al. 2015, Table S2), respectively. Thus, the UCYN-A3 sublineage also appears to have a wide global distribution and can co-occur with other UCYN-A sublineages.

Several UCYN-A nifH OTUs form a cluster with a small number of previously reported sequences in GenBank from the North Pacific (accession numbers LC013598, LC013602, LC013603 and LC013607; Shiozaki et al. 2015), the northeast Atlantic (accession numbers KF546393, KF546401, KF546415, KF546453 and KF546389; G. Wheeler unpubl. data) and Cape Verde islands in the eastern Atlantic Ocean (accession number HQ634491; S. Sudhaus \& J. LaRoche unpubl. data). Interestingly, sequences within this sublineage were present in all 4 of the next generation sequencing datasets investigated here and corresponded to a relative abundance of $22.3 \%$ in the Danish Strait (Fig. 2, Table S2). Thus,

Fig. 2. (A) Maximum likelihood (ML) tree of Atelocyanobacterium thalassa (UCYN-A) partial nifH nucleotide sequences (313 bp), constructed using operational taxonomic units (OTUs) generated from all UCYN-A sequences as available in GenBank (17 December 2015) and next generation sequencing based studies known to date. Phylogenetic analysis was conducted in MEGA 6.0. Branch lengths were determined using the Tamura-Nei model, bootstrap values were calculated using 1000 replicate trees and are displayed when greater than 50. The ML tree and associated metadata were visualized using the iTOL v2 web platform (Letunic \& Bork 2011). The presence (colored circle) or absence (no circle) of UCYN-A OTUs in each oceanic region is described to the right of the tree. OTUs that represent dominant sequence types for each sublineage are indicated with grey shading and labeled A1, A2, A3 and A4. The OTUs containing the genome sequenced UCYN-A nifH are indicated with an asterisk. (B) Total number of UCYN-A nifH reads available from GenBank and next generation sequencing (ngs) datasets for different oceanic regions for each of the sublineage OTU representatives (indicated with grey shading in A). The representative sequences are indicated with origin New Caledonia Lagoon (nc; Turk-Kubo et al. 2015), Arafura \& Coral Seas (acs; Messer et al. 2016), South Australian Bight (sab; Messer et al 2015), and the Danish Strait (ds; Bentzon-Tilia et al. 2015) 
despite the presence of only a few representatives of this sublineage in the GenBank nr database, next generation sequencing-based studies indicate that this novel UCYN-A sublineage, which we refer to henceforth as UCYN-A4, may be significant in some environments. Little is known about its global distribution at this time, and more studies that employ next generation sequencing will be required to better characterize their distribution. However, the presence of this sublineage in vastly different oceanic regions suggests that UCYN-A4 may have a wide geographic distribution, similar to other UCYN-A sublineages. Furthermore, based on the next generation sequencing data from the Danish Strait (Bentzon-Tilia et al. 2015), it appears likely that UCYN-A4 may be present at relatively high abundances in specific areas, yet since UCYN-A4 nifH sequences have largely evaded detection within clone library efforts, they may often be present at lower abundances compared to other UCYN-A sublineages.

One of the challenges emerging from the discovery of multiple UCYN-A sublineages is evaluating the specificity and cross-hybridization of molecular assays. Recently, the most widely used qPCR assay used to quantify UCYN-A, designed by Church et al. (2005a) (Table S1), was found to contain several mismatches to nifH sequences representing UCYN-A2 and UCYN-A3 sublineages (Thompson et al. 2014, Table 1). Similarly, in a compilation of all UCYN-A qPCR assays reported, we found that each of the primer/probe sets contained several mismatches to one or more of the UCYN-A sublineage OTU representatives reported in this study (Table 1). Thus, since UCYN-A sublineages frequently co-occur, nifH abundance and transcription may have been under- estimated in numerous studies if qPCR using only 1 assay was the only method for investigating UCYN-A presence and activity. To circumvent this problem, a qPCR assay targeting UCYN-A2 was designed by Thompson et al. (2014), which has been used in combination with the Church et al. (2005a) qPCR assay in several subsequent studies with the aim to evaluate abundances of the respective UCYN-A sublineages and to estimate the total abundance of UCYN-A (Bombar et al. 2014, Bonnet et al. 2015, Turk-Kubo et al. 2015, Rees et al. 2016). Interestingly, using the qPCR assay designed to target UCYN-A2 (5 total mismatches to UCYN-A1; Table 1), high abundances (up to $2 \times 10^{5}$ nifH gene copies $\mathrm{l}^{-1}$ ) were reported from the SIO pier in La Jolla, California (Thompson et al. 2014). Similarly, Bentzon-Tilia et al. (2015) measured UCYN-A abundances of up to $7.6 \times 10^{5}$ nifH gene copies $\mathrm{l}^{-1}$ using a qPCR assay with a total of 5 mismatches to UCYN-A1 in 2 temperate estuaries in the Danish Strait. These results suggest that sublineages that would not have been detected using the Church et al. (2005a) qPCR assay may be prevalent in some environments and could account for significant $\mathrm{N}_{2}$ fixation. Unfortunately, due to the short nifH fragment and the high similarity between the different sublineages (Fig. 2A), designing a qPCR assay to differentiate between UCYN-A2 and UCYNA3 is difficult, and in silico tests indicate that the UCYN-A2 qPCR assay designed by Thompson et al. (2014) does not contain sufficient mismatches to prevent cross-hybridization with the UCYN-A3 sublineage (Table 1). Consequently, with the increasing number of UCYN-A nifH sequences and the discovery of closely related sublineages, it will be important to re-evaluate the amplification specificity and cover-

Table 1. Number of total mismatches of primers and probes of all published qPCR assays designed to quantify Atelocyanobacterium thalassa (UCYN-A) to the operational taxonomic unit (OTU) representative of each UCYN-A sublineage

\begin{tabular}{|c|c|c|c|c|c|}
\hline \multirow{2}{*}{$\begin{array}{l}\text { qPCR assay name } \\
\text { (reference sequence } \\
\text { if available) }\end{array}$} & \multicolumn{4}{|c|}{$\begin{array}{l}\text { Number of total mismatches of primers and probes } \\
\text { to the OTU representative of each sublineage }\end{array}$} & \multirow[t]{2}{*}{ Reference } \\
\hline & $\begin{array}{l}\text { UCYN-A1 } \\
\text { (gi 213578830) }\end{array}$ & $\begin{array}{c}\text { UCYN-A2 } \\
\text { (gi } 671395380)\end{array}$ & $\begin{array}{c}\text { UCYN-A3 } \\
\text { (gi 308209564) }\end{array}$ & $\begin{array}{c}\text { UCYN-A4 } \\
\text { (sab Z1_1S_191307) }\end{array}$ & \\
\hline OTU0002 & 5 & 0 & 0 & 0 & Bentzon-Tilia et al. (2015) \\
\hline Group A (AF059642) & 2 & 5 & 4 & 4 & Church et al. (2005a) \\
\hline UCYN-A (HM210392) & 1 & 1 & 0 & 2 & Halm et al. (2012) \\
\hline UCYN-A-nifH-2 & 0 & 0 & 2 & 1 & Hashimoto et al. (2016) \\
\hline UCYN-A (HQ456051) & 0 & 0 & 2 & 2 & Kong et al. $(2011)^{\mathrm{a}}$ \\
\hline Group A (AF059627) & 0 & 4 & 5 & 4 & Langlois et al. (2008) \\
\hline Group A (AB665496) & 0 & 6 & 7 & 5 & Shiozaki et al. (2014) \\
\hline CBga (CB4713A1) & 6 & 0 & 1 & 1 & Short \& Zehr (2007) \\
\hline UCYN-A2 & 5 & 0 & 1 & 1 & Thompson et al. (2014) \\
\hline
\end{tabular}


age of UCYN-A nifH qPCR assays before making interpretations of ecotype distributions and abundances. In addition, evaluating the UCYN-A nifH sublineages present in a sample using an amplicon library is necessary in order to evaluate which qPCR assays should be used for estimating total UCYN-A abundances within a sample. The wide distribution and co-occurrence of UCYN-A sublineages suggests that if the UCYN-A sublineages represent distinct ecotypes they have overlapping niches. Thus, more information, including highly specific assays, possibly beyond the nifH gene fragment currently used, will be needed in order to evaluate what controls their spatial and temporal distribution patterns.

\section{VISUALIZATION TECHNIQUES ALLOW FOR INSIGHTS INTO CELL MORPHOLOGY AND PHYSIOLOGY}

Recent developments of UCYN-A-specific FISH probes have led to the first visualizations of UCYN-A cells and have resulted in a rapid increase in knowledge of the morphology and physiology of this unusual symbiosis. Early CARD-FISH studies investigating unicellular diazotrophs used the Nitro821R probe (Mazard et al. 2004), which targets the 16S rRNA gene of unicellular cyanobacterial diazotrophs. Using this approach, physiologically diverse species including Crocosphaera sp., Cyanothece sp., intracellular cyanobacterial symbionts of the marine diatom Climacodium frauenfeldianum as well as UCYN-A would be hybridized at the same time. In concurrence with nifH amplicon-based studies, cells that hybridized with the Nitro821R probe were numerically significant at times, indicating the importance of this group of diazotrophs in diverse marine locations including the Pacific Ocean (Bonnet et al. 2009), the Atlantic Ocean (Agawin et al. 2014, Riou et al. 2016), the New Caledonia coral lagoon (Biegala \& Raimbault 2008) and the Mediterranean Sea (Le Moal \& Biegala 2009, Le Moal et al. 2011). However, although specific morphological features and presence within various size fractions were observed, the lack of specificity of the probe and the co-occurrence of several unicellular cyanobacterial diazotrophs precluded links to the various species.

The large genome reduction (Tripp et al. 2010, Bombar et al. 2014) and tight coupling in nutrient exchange suggests an obligate symbiosis between UCYN-A and its associated eukaryotic partner (Krupke et al. 2015). Yet, the association is fragile and without careful sample processing, UCYN-A may be easily dislodged from the eukaryotic cell (Thompson et al. 2012, Krupke et al. 2013). Epifluorescence and scanning electron microscopy observations suggest that the UCYN-A cell may be connected to the surface of the eukaryotic partner in a loosely attached, yet intimate cell-surface interaction between the symbionts (Thompson et al. 2012, Krupke et al. 2013, 2014, 2015, Cabello et al. 2016, Cornejo-Castillo et al. 2016). However, using transmission electron microscopy (TEM), spherical bodies within Braarudosphaera bigelowii cells, separated from the eukaryotic cell cytoplasm by a single membrane, were identified as UCYN-A endosymbionts, suggesting that the association could also be intracellular (Hagino et al. 2013).

There are now several UCYN-A specific FISH probes that have been developed and applied to environmental samples, which has advanced the ability to link morphotypes with 16S rRNA gene phylotypes. Thus far, the most frequently reported observation with UCYN-A-specific probes (UCYN-A732 and/or UCYN-A159) is one UCYN-A cell per eukaryotic partner cell located on the polar end of the eukaryotic cell (Thompson et al. 2012, Krupke et al. 2013, 2015, Cabello et al. 2016). Interestingly, in a small fraction of observed associations, 2 hybridized UCYN-A cells have been reported on opposite ends of a single eukaryotic cell (Thompson et al. 2012, Cabello et al. 2016).

After the description of a second UCYN-A sublineage, UCYN-A2 (Thompson et al. 2014), CornejoCastillo et al. (2016) designed a double CARD-FISH assay to specifically target the 2 different UCYN-A sublineages. In the South Atlantic, they observed small prymnesiophyte cells associated with a single cell hybridized with the UCYN-A1 probe and multiple UCYN-A2 ( 3 to 10 cells) within a cellular pocket of the eukaryotic partner cell. Similar morphological observations of UCYN-A1 and UCYN-A2 have been observed at Stn ALOHA in the subtropical Pacific Ocean and at the SIO pier (Fig. 3). In comparing the genomes between UCYN-A1 and UCYN-A2, several genes determining cell shape and cell wall biogenesis were present in UCYN-A2 while absent in UCYN-A1, suggesting differences in how the 2 sublineages are associated with their eukaryotic partner cells (Bombar et al. 2014). Thus, for some UCYN-A sublineages, multiple cells may be associated with one eukaryotic partner cell, but how cell division occurs within these cell consortia is still not clear (Zehr 2015).

The eukaryotic UCYN-A partner cells have been visualized using several different CARD-FISH assays (Krupke et al. 2014, Cabello et al. 2016, Cornejo- 

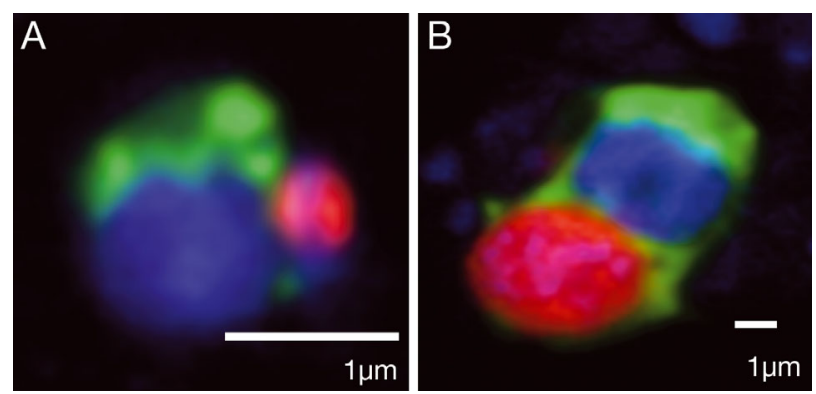

Fig. 3. Epifluorescence micrographs of Atelocyanobacterium thalassa (UCYN-A) (red) and its symbiotic partner (green) stained with catalyzed reporter deposition-fluorescence in situ hybridization (CARD-FISH) and DAPI at the Scripps Institute of Oceanography (SIO) pier, La Jolla, CA, USA. The nucleus of each host is visualized with DAPI stain (blue). (A) UCYN-A1 and its prymnesiophyte partner using UCYN-A1 732 and UPRYM-69 probes (Cornejo-Castillo et al. 2016). (B) UCYN-A2 targeted by the UCYN-A2 732 probe and the larger prymnesiophyte with the UBRADO69 probe (Cornejo-Castillo et al. 2016). Micrographs were obtained using Leica SP5 Confocal Microscope at the University of California, Santa Cruz Life Sciences Microscopy Center

Castillo et al. 2016). CARD-FISH, in combination with 18S rRNA tag sequencing, revealed UCYN-A in association with a small prymnesiophyte cell in all ocean basins, and suggests that the eukaryotic partner cells of UCYN-A1 and A2 are also widely distributed (Cabello et al. 2016, our Fig. 1). Based on observations of different sizes of the hosts, as well as recruitment of genomes from metagenomes of different size fractions, the cell consortia of UCYN-A1 appears to be smaller in size compared to UCYN-A2 (Thompson et al. 2014, Cabello et al. 2016, CornejoCastillo et al. 2016). Previously, Thompson et al. (2014) estimated the size of the UCYN-A2 cell consortia using microscopy and flow cytometry to be $\sim 7$ to $10 \mu \mathrm{m}$ in diameter. Interestingly, Hagino et al. (2013) observed B. bigelowii cells, that had an $18 \mathrm{~S}$
rRNA sequence identical to that of the UCYN-A2associated eukaryotic cells described by Thompson et al. (2014), to be $15 \mu \mathrm{m}$ in diameter with pentaliths. Together, these observations suggest that the eukaryotic partner cells may have different morphological stages and the consortia could thereby vary in size.

In addition to the differences in size of the eukaryotic partner cells, differences in the size of UCYN-A cells have also been observed. In the North Pacific and North Atlantic, small UCYN-A cells (0.5 to $1.2 \mu \mathrm{m}$ in diameter) associated with small eukaryotic cells ( 1 to $3 \mu \mathrm{m}$ in diameter) were found (Thompson et al. 2012, Krupke et al. 2014, 2015, our Table 2). In the North Atlantic, slightly larger associations have also been described, with UCYN-A cells of up to $3 \mu \mathrm{m}$ in diameter with a eukaryotic cell of up to $5.5 \mu \mathrm{m}$ in diameter co-occurring with the smaller, previously described UCYN-A consortia (Krupke et al. 2013). Interestingly, although these differences in cell size could represent cells in different stages of cell division, the samples that contained multiple size ranges of UCYN-A cells were collected near the Cape Verde islands, a region where sequences from multiple UCYN-A sublineages have been reported and where UCYN-A is thought to be responsible for the majority of the biological $\mathrm{N}_{2}$ fixation (Goebel et al. 2010, Turk et al. 2011). Unfortunately, it is not yet resolved how CARD-FISH observations can be linked to the defined UCYN-A nifH sublineages, since the 16S rRNA gene sequences of UCYN-A3 and UCYN-A4 sublineages are unknown (current knowledge of the different sublineages is summarized in Table 3). However, the known variation in cell sizes of the UCYN-A1 and UCYN-A2 sublineages and their eukaryotic partner cells suggests differences in physiology and nutrient requirements. In a recent metatranscriptome study, the number of nifH transcripts per UCYN-A2 cell were almost double compared to UCYN-A1, despite UCYN-A1 being

Table 2. The diameter of Atelocyanobacterium thalassa (UCYN-A) and associated eukaryotic cells estimated using halogenated in situ hybridization (HISH) or catalyzed reporter deposition-fluorescence in situ hybridization (CARD-FISH) assays and the respective probes used in each study. na: not available. The study by Cornejo-Castillo et al. (2016) has not been included because the measured diameters of the cells were not reported

\begin{tabular}{|lcccccc|}
\hline $\begin{array}{l}\text { UCYN-A cell } \\
\text { diameter }(\mu \mathrm{m})\end{array}$ & $\mathrm{N}$ & $\begin{array}{c}\text { Eukaryotic cell } \\
\text { diameter }(\mu \mathrm{m})\end{array}$ & $\mathrm{N}$ & UCYN-A probe & $\begin{array}{c}\text { Eukaryotic } \\
\text { probe }\end{array}$ \\
\hline $0.62 \pm 0.16$ & 19 & $1.36 \pm 0.24$ & 10 & UCYN-A732 & Not used & Thompson et al. (2012) \\
$1.36 \pm 0.45$ & 44 & $3.58 \pm 1.42$ & 8 & UCYN-A732, UCYN-A159 & Not used & Krupke et al. (2013) \\
$1.16 \pm 0.24$ & 52 & $2.26 \pm 0.75$ & 52 & UCYN-A732 & PRYM02 & Krupke et al. (2014) \\
$0.83 \pm 0.15$ & 44 & $1.66 \pm 0.23$ & 44 & UCYN-A732 & Urupke et al. (2015) \\
na & & $\sim 2.5$ & 2030 & UCYN-A732 & UPRYM-69 (UCYN-A1 partner) & Cabello et al. (2016) \\
na & & $4-5$ & 17 & UCYN-A732 & UBRADO-69 (UCYN-A2 partner) & Cabello et al. (2016) \\
\end{tabular}


Table 3. Synthesis of available sequence information, assays available to detect or visualize Atelocyanobacterium thalassa (UCYN-A), and known morphology of UCYN-A sublineages. CARD-FISH: catalyzed reporter deposition-fluorescence in situ hybridization

\begin{tabular}{|c|c|c|c|c|}
\hline & UCYN-A1 & UCYN-A2 & UCYN-A3 & UCYN-A4 \\
\hline \multicolumn{5}{|l|}{ Sequence information } \\
\hline Full genome & Yes & Yes & No & No \\
\hline nifH gene & Yes & Yes & Yes & Yes \\
\hline 16S rRNA gene & Yes & Yes & Unknown & Unknown \\
\hline 18S rRNA gene from eukaryotic partner & Yes & Yes & Unknown & Unknown \\
\hline \multicolumn{5}{|l|}{ Assays } \\
\hline nifH qPCR assay & Yes, not specific & Yes, not specific & Yes, not specific & Yes, not specific \\
\hline 16S rRNA gene probe (CARD-FISH) & Yes & Yes & Unknown & Unknown \\
\hline 18S rRNA gene probe (CARD-FISH) & Yes & Yes & Unknown & Unknown \\
\hline \multicolumn{5}{|l|}{ Known morphology } \\
\hline Number of cells per eukaryotic partner & $1-2$ & $\sim 3-10$ & Unknown & Unknown \\
\hline Size of consortia $(\mu \mathrm{m})$ & $1-3$ & $4-10$ & Unknown & Unknown \\
\hline
\end{tabular}

more abundant in the sample, possibly reflecting the additional nutrient requirements of the larger eukaryotic partner (Cornejo-Castillo et al. 2016). Identification and visualization of additional UCYN-A sublineages will therefore be important for understanding their physiology and to estimate their contribution to marine $\mathrm{N}_{2}$ fixation.

\section{FUTURE DIRECTIONS AND CONCLUSIONS}

Because of the low abundances of UCYN-A compared to other marine microorganisms, UCYN-A nifH sequences were rarely detected within early metagenomic datasets (Johnston et al. 2005). With the availability of the UCYN-A1 and UCYN-A2 genomes and the 18S rRNA gene sequences of the corresponding eukaryotic partners, in combination with a great increase in sequencing depth, screening of metagenomic and metatranscriptomic datasets for UCYN-A have become more successful. Within the metagenomic datasets from the Tara-Oceans Expedition, UCYN-A-associated prymnesiophytes appeared to be consistently present (albeit at low relative abundances) in widely distributed regions, including areas where UCYN-A diversity and abundance are not yet well known (Cabello et al. 2016, our Fig. 1). In addition, large fractions of UCYN-A1 and UCYN-A2 genomes (genome recovery of close to $100 \%$ for some samples) were recently recruited from metagenomes and metatranscriptomes from 2 stations in the South Atlantic Ocean (Cornejo-Castillo et al. 2016). Thus, with the increasing amounts of sequencing data available and target genes beyond the nifH gene, knowledge of the global distribution patterns, transcriptional activity and abundance of this symbiosis is expected to rapidly increase in the near future.

Over the past decade, multiple novel methods and approaches have been used to study UCYN-A, which has led to remarkable discoveries about this unusual symbiosis. In the future, it will be important to use cross comparisons for validation of measurements using different assays and methods. For example, current qPCR methods result in an order of magnitude higher abundances of UCYN-A compared to CARD-FISH counts (Krupke et al. 2013), and the evaluation of primer specificity for different UCYN-A sublineages of both qPCR and CARD-FISH assays and how they compare have not yet been resolved. Based on the evidence of diverse lifestyles of different UCYN-A sublineages, designing novel assays to distinguish between the sublineages will be important for elucidating UCYN-A ecotype diversity and distribution. Furthermore, renewed efforts to isolate this association are needed to make breakthroughs in understanding the biology of this unusual symbiosis, as there remain many unanswered questions about the structural basis of the symbiosis, cell division and the communication between partner cells.

Acknowledgements. We thank Lauren Messer for providing metadata from her sample sites, and Benjamin Abrams and the UCSC Life Science Microscopy Center for microscopy assistance. H.F. was supported by the Swedish Research Council VR 637-2013-7502, and H.F., K.T.-K. and J.P.Z. were supported through the NSF C-MORE (\#EF0424599) and the Simons Collaboration on Ocean Processes and Ecology (SCOPE). M.C.M.-M. was supported by a Marie Curie International Outgoing Fellowship within the 7th European Community Framework Programme. 


\section{LITERATURE CITED}

Agawin NSR, Benavides M, Busquets A, Ferriol P, Stal LJ, Arístegui J (2014) Dominance of unicellular cyanobacteria in the diazotrophic community in the Atlantic Ocean. Limnol Oceanogr 59:623-637

Benavides M, Agawin NSR, Arístegui J, Ferriol P, Stal LJ (2011) Nitrogen fixation by Trichodesmium and small diazotrophs in the subtropical northeast Atlantic. Aquat Microb Ecol 65:43-53

Benavides M, Moisander PH, Daley MC, Bode A, Arístegui J (2016) Longitudinal variability of diazotroph abundances in the subtropical North Atlantic Ocean. J Plankton Res 38:662-672

> Bench SR, Heller P, Frank I, Arciniega M, Shilova IN, Zehr JP (2013) Whole genome comparison of six Crocosphaera watsonii strains with differing phenotypes. J Phycol 49: 786-801

> Bentzon-Tilia M, Traving SJ, Mantikci M, Knudsen-Leerbeck H, Hansen JL, Markager S, Riemann L (2015) Significant $\mathrm{N}_{2}$ fixation by heterotrophs, photoheterotrophs and heterocystous cyanobacteria in two temperate estuaries. ISME J 9:273-285

Biegala IC, Raimbault P (2008) High abundance of diazotrophic picocyanobacteria $(<3 \mu \mathrm{m})$ in a Southwest Pacific coral lagoon. Aquat Microb Ecol 51:45-53

Bombar D, Heller P, Sanchez-Baracaldo P, Carter BJ, Zehr JP (2014) Comparative genomics reveals surprising divergence of two closely related strains of uncultivated UCYN-A cyanobacteria. ISME J 8:2530-2542

- Bonnet S, Biegala IC, Dutrieux P, Slemons LO, Capone DG (2009) Nitrogen fixation in the western equatorial Pacific: rates, diazotrophic cyanobacterial size class distribution, and biogeochemical significance. Global Biogeochem Cycles 23:GB3012

> Bonnet S, Rodier M, Turk-Kubo KA, Germineaud C and others (2015) Contrasted geographical distribution of $\mathrm{N}_{2}$ fixation rates and nifH phylotypes in the Coral and Solomon Seas (southwestern Pacific) during austral winter conditions. Global Biogeochem Cycles 29: 1874-1892

Brown SM, Jenkins BD (2014) Profiling gene expression to distinguish the likely active diazotrophs from a sea of genetic potential in marine sediments. Environ Microbiol 16:3128-3142

- Cabello AM, Cornejo-Castillo FM, Raho N, Blasco D and others (2016) Global distribution and vertical patterns of a prymnesiophyte-cyanobacteria obligate symbiosis. ISME J 10:693-706

Capone DG, Zehr JP, Paerl HW, Bergman B, Carpenter EJ (1997) Trichodesmium, a globally significant marine cyanobacterium. Science 276:1221-1229

> Capone DG, Burns JA, Montoya JP, Subramaniam A and others (2005) Nitrogen fixation by Trichodesmium spp.: an important source of new nitrogen to the tropical and subtropical North Atlantic Ocean. Global Biogeochem Cycles 19:GB2024

> Caporaso JG, Kuczynski J, Stombaugh J, Bittinger K and others (2010) QIIME allows analysis of high-throughput community sequencing data. Nat Methods 7:335-336

> Cheung S, Xia X, Guo C, Liu H (2016) Diazotroph community structure in the deep oxygen minimum zone of the Costa Rica Dome. J Plankton Res 38:380-391

> Church MJ, Jenkins BD, Karl DM, Zehr JP (2005a) Vertical distributions of nitrogen-fixing phylotypes at Stn
ALOHA in the oligotrophic North Pacific Ocean. Aquat Microb Ecol 38:3-14

Church MJ, Short CM, Jenkins BD, Karl DM, Zehr JP (2005b) Temporal patterns of nitrogenase gene (nifH) expression in the oligotrophic North Pacific Ocean. Appl Environ Microbiol 71:5362-5370

Church MJ, Mahaffey C, Letelier RM, Lukas R, Zehr JP, Karl DM (2009) Physical forcing of nitrogen fixation and diazotroph community structure in the North Pacific subtropical gyre. Global Biogeochem Cycles 23:GB2020

Coleman ML, Chisholm SW (2010) Ecosystem-specific selection pressures revealed through comparative population genomics. Proc Natl Acad Sci USA 107:1863418639

Cornejo-Castillo FM, Cabello AM, Salazar G, Sa P and others (2016) Cyanobacterial symbionts diverged in the late Cretaceous towards lineage-specific nitrogen fixation factories in single-celled phytoplankton. Nat Commun 7: 11071

> Dekaezemacker J, Bonnet S (2011) Sensitivity of $\mathrm{N}_{2}$ fixation to combined nitrogen forms $\left(\mathrm{NO}_{3}\right.$ and $\left.\mathrm{NH}_{4}\right)$ in two strains of the marine diazotroph Crocosphaera watsonii (Cyanobacteria). Mar Ecol Prog Ser 438:33-46

Dixon R, Kahn D (2004) Genetic regulation of biological nitrogen fixation. Nat Rev Microbiol 2:621-631

Edgar RC, Haas BJ, Clemente JC, Quince C, Knight R (2011) UCHIME improves sensitivity and speed of chimera detection. Bioinformatics 27:2194-2200

Falcón LI, Carpenter EJ, Cipriano F, Bergman B, Capone DG (2004) $\mathrm{N}_{2}$ Fixation by unicellular bacterioplankton from the Atlantic and Pacific Oceans: phylogeny and in situ rates. Appl Environ Microbiol 70:765-770

> Farnelid H, Andersson AF, Bertilsson S, Al-Soud WA and others (2011) Nitrogenase gene amplicons from global marine surface waters are dominated by genes of noncyanobacteria. PLoS ONE 6:e19223

Fong AA, Karl DM, Lukas R, Letelier RM, Zehr JP, Church MJ (2008) Nitrogen fixation in an anticyclonic eddy in the oligotrophic North Pacific Ocean. ISME J 2:663-676

> Garcia N, Raimbault P, Sandroni V (2007) Seasonal nitrogen fixation and primary production in the Southwest Pacific: nanoplankton diazotrophy and transfer of nitrogen to picoplankton organisms. Mar Ecol Prog Ser 343:25-33

Goebel NL, Edwards CA, Carter BJ, Achilles KM, Zehr JP (2008) Growth and carbon content of three differentsized diazotrophic cyanobacteria observed in the subtropical North Pacific. J Phycol 44:1212-1220

> Goebel NL, Turk KA, Achilles KM, Paerl R and others (2010) Abundance and distribution of major groups of diazotrophic cyanobacteria and their potential contribution to $\mathrm{N}_{2}$ fixation in the tropical Atlantic Ocean. Environ Microbiol 12:3272-3289

Hagino K, Onuma R, Kawachi M, Horiguchi T (2013) Discovery of an endosymbiotic nitrogen-fixing cyanobacterium UCYN-A in Braarudosphaera bigelowii (Prymnesiophyceae). PLoS ONE 8:e81749

Halm H, Lam P, Ferdelman TG, Lavik G and others (2012) Heterotrophic organisms dominate nitrogen fixation in the South Pacific Gyre. ISME J 6:1238-1249

> Hashimoto R, Watai H, Miyahara K, Sako Y (2016) Title spatial and temporal variability of unicellular diazotrophic cyanobacteria in the eastern Seto Inland Sea. Fish Sci 82: 459-471

Hewson I, Moisander PH, Morrison AE, Zehr JP (2007) Diazotrophic bacterioplankton in a coral reef lagoon: phylo- 
geny, diel nitrogenase expression and response to phosphate enrichment. ISME J 1:78-91

- Huang Y, Niu B, Gao Y, Fu L, Li W (2010) CD-HIT Suite: a web server for clustering and comparing biological sequences. Bioinformatics 26:680-682

Johnston AWB, Li Y, Ogilvie L (2005) Metagenomic marine nitrogen fixation: Feast or famine? Trends Microbiol 13: 416-420

Karl D, Letelier R, Tupas L, Dore J, Christian J, Hebel D (1997) The role of nitrogen fixation in biogeochemical cycling in the subtropical North Pacific Ocean. Nature 388:533-538

Kashtan N, Roggensack SE, Rodrigue S, Thompson JW and others (2014) Single-cell genomics reveals hundreds of coexisting subpopulations in wild Prochlorococcus. Science 344:416-420

Knapp AN (2012) The sensitivity of marine $\mathrm{N}_{2}$ fixation to dissolved inorganic nitrogen. Front Microbiol 3:374

Kong L, Jing H, Kataoka T, Sun J, Liu H (2011) Phylogenetic diversity and spatio-temporal distribution of nitrogenase genes (nifH) in the northern South China Sea. Aquat Microb Ecol 65:15-27

- Krupke A, Musat N, LaRoche J, Mohr W and others (2013) In situ identification and $\mathrm{N}_{2}$ and $\mathrm{C}$ fixation rates of uncultivated cyanobacteria populations. Syst Appl Microbiol 36: 259-271

Krupke A, Lavik G, Halm H, Fuchs BM, Amann RI, Kuypers MMM (2014) Distribution of a consortium between unicellular algae and the $\mathrm{N}_{2}$ fixing cyanobacterium UCYNA in the North Atlantic Ocean. Environ Microbiol 16: 3153-3167

Krupke A, Mohr W, Laroche J, Fuchs BM, Amann RI, Kuypers MMM (2015) The effect of nutrients on carbon and nitrogen fixation by the UCYN-A-haptophyte symbiosis. ISME J 9:1635-1647

> Langlois RJ, LaRoche J, Raab PA (2005) Diazotrophic diversity and distribution in the tropical and subtropical Atlantic Ocean. Appl Environ Microbiol 71:7910-7919

Langlois RJ, Hümmer D, LaRoche J (2008) Abundances and distributions of the dominant nifH phylotypes in the northern Atlantic Ocean. Appl Environ Microbiol 74:1922-1931

Langlois RJ, Mills MM, Ridame C, Croot P, LaRoche J (2012) Diazotrophic bacteria respond to Saharan dust additions. Mar Ecol Prog Ser 470:1-14

> Le Moal M, Biegala IC (2009) Diazotrophic unicellular cyanobacteria in the northwestern Mediterranean Sea: a seasonal cycle. Limnol Oceanogr 54:845-855

Le Moal M, Collin H, Biegala IC (2011) Intriguing diversity among diazotrophic picoplankton along a Mediterranean transect: a dominance of rhizobia. Biogeosciences 8: $827-840$

Letunic I, Bork P (2011) Interactive Tree Of Life v2: online annotation and display of phylogenetic trees made easy. Nucl Acids Res 39:475-478

Ludwig W, Strunk O, Westram R, Richter L and others (2004) ARB: a software environment for sequence data. Nucleic Acids Res 32:1363-1371

> Luo YW, Doney SC, Anderson LA, Benavides M and others (2012) Database of diazotrophs in global ocean: abundance, biomass and nitrogen fixation rates. Earth Syst Sci Data 4:47-73

Man-Aharonovich D, Kress N, Zeev EB, Berman-Frank I, Béjà O (2007) Molecular ecology of nifH genes and transcripts in the eastern Mediterranean Sea. Environ Microbiol 9:2354-2363
Mazard SL, Fuller NJ, Orcutt KM, Scanlan DJ, Bridle O (2004) PCR analysis of the distribution of unicellular cyanobacterial diazotrophs in the Arabian Sea. Appl Environ Microbiol 70:7355-7364

Messer LF, Doubell M, Jeffries TC, Brown MV, Seymour JR (2015) Prokaryotic and diazotrophic population dynamics within a large oligotrophic inverse estuary. Aquat Microb Ecol 74:1-15

Messer LF, Mahaffey C, Robinson CM, Jeffries TC and others (2016) High levels of heterogeneity in diazotroph diversity and activity within a putative hotspot for marine nitrogen fixation. ISME J 10:1499-1513

Moisander PH, Beinart RA, Hewson I, White AE and others (2010) Unicellular cyanobacterial distributions broaden the oceanic $\mathrm{N}_{2}$ fixation domain. Science 327:1512-1514

Moisander PH, Zhang R, Boyle EA, Hewson I, Montoya JP, Zehr JP (2012) Analogous nutrient limitations in unicellular diazotrophs and Prochlorococcus in the South Pacific Ocean. ISME J 6:733-744

Montoya JP, Holl CM, Zehr JP, Hansen A, Villareal TA, Capone DG (2004) High rates of $\mathrm{N}_{2}$ fixation by unicellular diazotrophs in the oligotrophic Pacific Ocean. Nature 430:1027-1032

Moore CM, Mills MM, Arrigo KR, Berman-Frank I and others (2013) Processes and patterns of oceanic nutrient limitation. Nat Geosci 6:701-710

Musat N, Stryhanyuk H, Bombach P, Adrian L, Audinot JN, Richnow HH (2014) The effect of FISH and CARD-FISH on the isotopic composition of ${ }^{13} \mathrm{C}$ - and ${ }^{15} \mathrm{~N}$-labeled Pseudomonas putida cells measured by nanoSIMS. Syst Appl Microbiol 37:267-276

Ratten JM, LaRoche J, Desai DK, Shelley RU and others (2015) Sources of iron and phosphate affect the distribution of diazotrophs in the North Atlantic. Deep-Sea Res II 116:332-341

Rees AP, Turk-Kubo KA, Al-Moosawi L, Alliouane S, Gazeau F, Hogan ME, Zehr JP (2016) Ocean acidification impacts on nitrogen fixation in the coastal western Mediterranean Sea. Estuar Coast Shelf Sci 2:1-13

> Riou V, Fonseca-Batista D, Roukaerts A, Biegala IC and others (2016) Importance of $\mathrm{N}_{2}$-fixation on the productivity at the northwestern Azores Current/Front System, and the abundance of diazotrophic unicellular cyanobacteria. PLoS ONE 11:e0150827

> Ryther JH, Dunstan WM (1971) Nitrogen, phosphorus, and eutrophication in the coastal marine environment. Science 171:1008-1013

Scavotto RE, Dziallas C, Bentzon-Tilia M, Riemann L, Moisander PH (2015) Nitrogen-fixing bacteria associated with copepods in coastal waters of the North Atlantic Ocean. Environ Microbiol 17:3754-3765

Shiozaki T, Chen YLL, Lin YH, Taniuchi Y, Sheu DS, Furuya K, Chen HY (2014) Seasonal variations of unicellular diazotroph groups A and B, and Trichodesmium in the northern South China Sea and neighboring upstream Kuroshio Current. Cont Shelf Res 80:20-31

Shiozaki T, Nagata T, Ijichi M, Furuya K (2015) Nitrogen fixation and the diazotroph community in the temperate coastal region of the northwestern North Pacific. Biogeosciences 12:4751-4764

> Short SM, Zehr JP (2007) Nitrogenase gene expression in the Chesapeake Bay Estuary. Environ Microbiol 9: 1591-1596

Sohm JA, Webb EA, Capone DG (2011) Emerging patterns of marine nitrogen fixation. Nat Rev Microbiol 9:499-508 
Sohm JA, Ahlgren NA, Thomson ZJ, Williams C and others (2016) Co-occurring Synechococcus ecotypes occupy four major oceanic regimes defined by temperature, macronutrients and iron. ISME J 10:333-345

Subramaniam A, Yager PL, Carpenter EJ, Mahaffey C and others (2008) Amazon River enhances diazotrophy and carbon sequestration in the tropical North Atlantic Ocean. Proc Natl Acad Sci USA 105:10460-10465

Thompson AW, Foster RA, Krupke A, Carter BJ and others (2012) Unicellular cyanobacterium symbiotic with a single-celled eukaryotic alga. Science 337 : 1546-1550

Thompson A, Carter BJ, Turk-Kubo K, Malfatti F, Azam F, Zehr JP (2014) Genetic diversity of the unicellular nitrogen-fixing cyanobacteria UCYN-A and its prymnesiophyte host. Environ Microbiol 16:3238-3249

Tripp HJ, Bench SR, Turk KA, Foster RA and others (2010) Metabolic streamlining in an open-ocean nitrogen-fixing cyanobacterium. Nature 464:90-94

Turk KA, Rees AP, Zehr JP, Pereira N and others (2011) Nitrogen fixation and nitrogenase (nifH) expression in tropical waters of the eastern North Atlantic. ISME J 5: 1201-1212

Turk-Kubo KA, Achilles KM, Serros TRC, Ochiai M, Montoya JP, Zehr JP (2012) Nitrogenase (nifH) gene expression in diazotrophic cyanobacteria in the tropical North Atlantic in response to nutrient amendments. Front Microbiol 3:386

Turk-Kubo KA, Frank IE, Hogan ME, Desnues A, Bonnet S, Zehr JP (2015) Diazotroph community succession during the VAHINE mesocosm experiment (New Caledonia lagoon). Biogeosciences 12:7435-7452

Villareal TA (1990) Laboratory culture and preliminary characterization of the nitrogen-fixing Rhizosolenia-Richelia symbiosis. Mar Ecol 11:117-132

Villareal TA (1991) Nitrogen-fixation by the cyanobacterial symbiont of the diatom genus Hemiaulus. Mar Ecol Prog Ser 76:201-204

Villareal TA (1994) Widespread occurrence of the Hemialus-

Editorial responsibility: Eva Lindström, Uppsala, Sweden cyanobacterial symbiosis in the southwest North Atlantic Ocean. Bull Mar Sci 54:1-7

Villareal TA, Carpenter EJ (1989) Nitrogen fixation, suspension characteristics, and chemical composition of Rhizosolenia mats in the central North Pacific gyre. Biol Oceanogr 6:327-346

> Ward BA, Dutkiewicz S, Moore CM, Follows MJ (2013) Iron, phosphorus, and nitrogen supply ratios define the biogeography of nitrogen fixation. Limnol Oceanogr 58: 2059-2075

Webb EA, Ehrenreich IM, Brown SL, Valois FW, Waterbury JB (2009) Phenotypic and genotypic characterization of multiple strains of the diazotrophic cyanobacterium, Crocosphaera watsonii, isolated from the open ocean. Environ Microbiol 11:338-348

Xiao P, Jiang Y, Liu Y, Tan W, Li W, Li R (2015) Re-evaluation of the diversity and distribution of diazotrophs in the South China Sea by pyrosequencing the nifH gene. Mar Freshw Res 66:681-691

Zehr JP (2015) How single cells work together. Science 349: 1163-1164

- Zehr JP, Mellon MT, Zani S, York N (1998) New nitrogenfixing microorganisms detected in oligotrophic oceans by amplification of nitrogenase (nifH) genes Appl Environ Microbiol 64:3444-3450

Zehr JP, Waterbury JB, Turner PJ, Montoya JP and others (2001) Unicellular cyanobacteria fix $\mathrm{N}_{2}$ in the subtropical North Pacific Ocean. Nature 412:635-638

Zehr JP, Montoya JP, Jenkins BD, Hewson I and others (2007) Experiments linking nitrogenase gene expression to nitrogen fixation in the North Pacific subtropical gyre. Limnol Oceanogr 52:169-183

Zehr JP, Bench SR, Carter BJ, Hewson I and others (2008) Globally distributed uncultivated oceanic $\mathrm{N}_{2}$-fixing cyanobacteria lack oxygenic photosystem II. Science 322:1110-1112

Zhang J, Kobert K, Flouri T, Stamatakis A (2014) PEAR: a fast and accurate Illumina Paired-End reAd mergeR. Bioinformatics 30:614-620

Submitted: April 27, 2016; Accepted: July 16, 2016 Proofs received from author(s): September 5, 2016 